
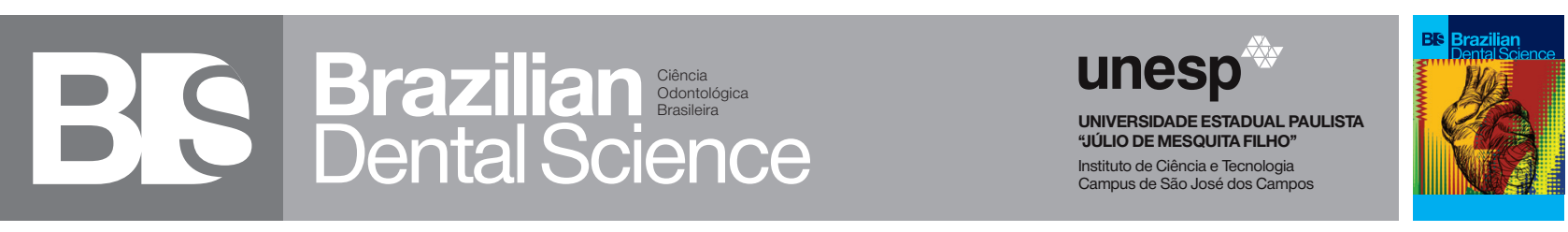

\title{
Effects of different degrees of acidity and concentration of bleaching agents on human enamel mineral content and surface morphology over time
}

\author{
Efeitos de diferentes graus de acidez e concentração de agentes clareadores no conteúdo mineral e morfologia superficial do \\ esmalte humano ao longo do tempo

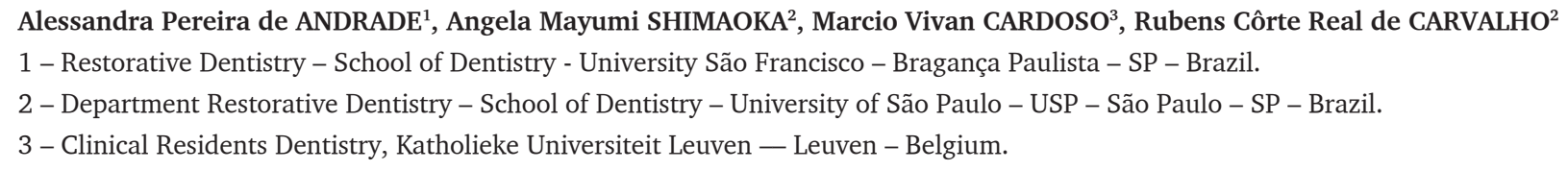

\section{ABSTRACT}

Objective: The aim of this study was to evaluate the effect of $\mathrm{pH}$ and concentration of bleaching agents on the mineral content and surface morphology of human dental enamel for 14 days. Material and Methods: Eighty human central incisors were randomly divided into 8 groups $(\mathrm{n}=10)$ : G1-7.5\% hydrogen peroxide/ $\mathrm{pH}=9.0$; $\mathrm{G} 2-9.5 \%$ hydrogen peroxide/pH=9.0; G3$7.5 \%$ hydrogen peroxide/ $\mathrm{pH}=7.0$; $\mathrm{G} 4-9.5 \%$ hydrogen peroxide $/ \mathrm{pH}=7.0 ; \quad \mathrm{G} 5-10 \%$ carbamide peroxide/ $\mathrm{pH}=5.0$; G6-16\% carbamide peroxide/pH=5.0; G7$37 \%$ phosphoric acid 15s (positive control); G8-no treatment (negative control). The mineral analysis of the bleaching gel collected was assessed by ICP-AES and surface morphology was observed by SEM. Results: Friedman and Dunn's statistical test demonstrated significant differences among the proposed treatments $(\mathrm{p}<0.01)$. No significant difference was found among groups treated with hydrogen peroxide (G1, G2, G3, and G4) or among groups G5, G6 and G7 ( $>>0.01$ ). However, the latter groups showed significantly higher values as compared to groups G1, G2, G3 and G4 $(\mathrm{p}<0.01)$. Conclusion: Alteration in enamel mineral content may not be influenced by concentration when bleaching agents with the same $\mathrm{pH}$ are compared. The most apparent alterations in mineral content and surface morphology may be noted when more acidic products are used. The daily mineral content measurement may not be influenced by repeated applications of bleaching agents.

\section{KEYWORDS}

Dental bleaching; Mineral content; Enamel; Peroxide; Demineralization; $\mathrm{pH}$.

\section{RESUMO}

Objetivo: Este estudo avaliou o efeito do $\mathrm{pH}$ e da concentração de agentes clareadores no conteúdo mineral e na morfologia da superfície do esmalte dental humano durante 14 dias. Material e Métodos: Oitenta incisivos centrais humanos foram aleatoriamente divididos em 8 grupos $(\mathrm{n}=10)$ : G1-peróxido de hidrogênio 7.5\% / $\mathrm{pH}$ = 9.0; G2 - peróxido de hidrogênio 9.5\%/pH = 9,0; G3 peróxido de hidrogênio 7.5\%/pH = 7,0; G4-de peróxido de hidrogênio 9.5\% / pH = 7,0; G5 - Peróxido de carbamida $10 \% / \mathrm{pH}=5.0 ; \mathrm{G} 6$ - peróxido de carbamida $16 \% / \mathrm{pH}=$ 5.0; G7- ácido fosfórico 37\% (controle positivo); G8 - sem tratamento (controle negativo). A análise mineral do gel clareador coletado foi avaliada por ICP-AES e a morfologia da superfície foi observada por MEV. Resultados: Os testes estatísticos de Friedman e Dunn demonstraram diferenças significativas entre os tratamentos propostos $(\mathrm{p}<0,01)$. Nenhuma diferença significativa foi encontrada entre os grupos tratados com peróxido de hidrogênio (G1, G2, G3 e G4) ou entre os grupos G5, G6 e G7 (p>0,01), no entanto, os estes grupos apresentaram valores significativamente maiores em relação aos grupos G1, G2, G3 e G4 (p <0,01). Conclusão: Alterações no conteúdo mineral do esmalte não foram influenciadas pela concentração dos agentes clareadores quando os mesmos $\mathrm{pH}$ são comparados. As alterações mais significativas no conteúdo mineral e na morfologia da superfície foram notadas quando clareadores mais ácidos foram utilizados. A mensuração diária do conteúdo mineral não foi influenciada por repetidas aplicações de agentes clareadores.

\section{PALAVRAS-CHAVE}

Clareamento Dental; Conteúdo mineral; Esmalte; Peroxido; Desmineralização; pH. 


\section{INTRODUCTION}

$\mathrm{D}$ ental bleaching has become one of the most popular aesthetic procedures over the last ten years. The technique related to this treatment involves the direct contact of the bleaching agent with tooth surfaces for an extended period. During this treatment, organic molecules responsible for tooth discoloration are degraded into less complex molecules, thus resulting in reduction or elimination of discoloration [1].

Since the introduction of the Nightguard Vital Bleaching technique using 10\% carbamide peroxide [2], studies have been conducted to evaluate the possible effects produced on dental tissues during and after whitening procedures. Despite the favorable results achieved with bleaching treatment $[3,4]$, there are many controversies as regards its adverse effects [5] such as dental sensitivity during treatment, a decrease in enamel surface hardness $[4,6,7]$, volume and mineral loss [8] and morphologic alterations after exposure to bleaching agents [9-11]. The controversies presented in the literature are not only related to the results found by different research groups, but also to the significant variety of methods that have been used to investigate the possible effects of bleaching agents on the physical and chemical properties of enamel [12-15].

Thus, despite a large number of studies whose central subject is the dental bleaching procedure, there are still questions about the effect of bleaching products on dental hard tissues. In this context, chemical analyses have suggested alterations in the mineral content of teeth submitted to bleaching procedures $[1,4,8,12,13,15,16]$. Moreover, the vast number of bleaching agents currently available in the market provides the clinician with a considerable variety of products with different combinations regarding composition, concentration acidity and treatment protocols.
All of these characteristics may play an essential role in the mineral content of bleached enamel [12], and should then be considered explicitly in the search for a more reliable treatment, which could be concomitantly effective and harmless. Therefore, this in vitro study evaluated the effect of bleaching agents with different acidities and concentrations on the mineral content and surface morphology of human dental enamel for 14 days. The null hypothesis tested is twofold: (i) the degree of demineralization of enamel submitted to bleaching treatment is not affected by chemical characteristics of bleaching agents, namely concentration and acidity; and (ii) the degree of demineralization does not change in a daily basis.

\section{METHODS AND MATERIALS}

This study was approved by the Research Ethics Committee, School of Dentistry of the University of São Paulo (protocol 05/05).

\section{Experimental Design}

The variables evaluated were bleaching agents (with different $\mathrm{pH}$ and concentration) and treatment time. The bleaching agents used in this study are described in Table 1, as well as the concentration of their main component, their $\mathrm{pH}$, and respective treatment protocols. The $\mathrm{pH}$ of each bleaching agent was measured using a pH meter (F-21 Horiba Group, Kyoto, Japan) as previously described by Price et al. [17]. The 80 experimental units were randomly divided into 8 groups $(n=10)$, i. e. 6 experimental groups in which samples were treated with different bleaching agents: G1-7.5\% hydrogen peroxide/ $\mathrm{pH}=9.0 ; \mathrm{G} 2-9.5 \%$ hydrogen peroxide $/ \mathrm{pH}=9.0$; G3-7.5\% hydrogen peroxide/pH=7.0; G4-9.5\% hydrogen peroxide/pH=7.0; G5-10\% carbamide peroxide/ $\mathrm{pH}=5.0$; G6-16\% carbamide peroxide/ $\mathrm{pH}=5.0 ; 1$ positive control group in which samples were treated with $35 \%$ phosphoric acid for 15 seconds; and 1 negative control group 
in which samples were kept in Milli-Q water (Millipore). The second factor under study was time (moment of treatment). Measurements were taken on a daily basis from the first to the seventh day. Afterwards, one more measurement was taken on the fourteenth day.

Table I - Description of the experimental design, techniques specifications of the materials used and treatment time

\begin{tabular}{|c|c|c|c|c|}
\hline $\begin{array}{l}\text { Group } \\
(n=10)\end{array}$ & Product (Manufacturer) & $\begin{array}{l}\text { Active } \\
\text { agent }\end{array}$ & pH & $\begin{array}{l}\text { Treatment } \\
\text { time }\end{array}$ \\
\hline G1 & $\begin{array}{l}\text { Excel } 3 \text { Day White (Discus } \\
\text { Dental, Culver City, CA, USA) }\end{array}$ & $7.5 \% \mathrm{HP}$ & 9.0 & $1 \mathrm{~h} /$ day \\
\hline G2 & $\begin{array}{l}\text { Excel 3 Day White (Discus } \\
\text { Dental, Culver City, CA, USA) }\end{array}$ & $9.5 \% \mathrm{HP}$ & 9.0 & 1h/day \\
\hline G3 & $\begin{array}{c}\text { Pola Day (SDI, Bayswater, VIC, } \\
\text { Australia) }\end{array}$ & $7.5 \% \mathrm{HP}$ & 7.0 & 1h/day \\
\hline G4 & $\begin{array}{l}\text { Pola Day (SDI, Bayswater, VIC, } \\
\text { Australia) }\end{array}$ & $9.5 \% \mathrm{HP}$ & 7.0 & 1h/day \\
\hline G5 & $\begin{array}{l}\text { VivaStyle (Ivoclar Vivadent, } \\
\text { Schaan, Liechtenstein) }\end{array}$ & $10 \% \mathrm{CP}$ & 5.0 & $8 \mathrm{~h} /$ day \\
\hline G6 & $\begin{array}{l}\text { VivaStyle (Ivoclar Vivadent, } \\
\text { Schaan, Liechtenstein) }\end{array}$ & $16 \% \mathrm{CP}$ & 5.0 & $8 \mathrm{~h} /$ day \\
\hline G7 & $\begin{array}{l}\text { Total Etch (Ivoclar Vivadent, } \\
\text { Schaan, Liechtenstein) - posi- } \\
\text { tive control }\end{array}$ & $37 \% \mathrm{PA}$ & 0.9 & $15 s$ \\
\hline G8 & $\begin{array}{c}\text { Milli-Q water (Millipore, Merck } \\
\text { KGaA, Darmstadt, Germany) - } \\
\text { negative control }\end{array}$ & - & 7.0 & $24 \mathrm{~h}$ \\
\hline & $\begin{array}{r}\text { ogen peroxide, } \mathrm{CP} \text { - carbami } \\
\text { acid }\end{array}$ & pero) & & sphoric \\
\hline
\end{tabular}

\section{Dental specimen selection criteria}

After prophylaxis, all the freshly extracted, non-carious human central incisors were examined under 40x magnification (SZ40, Olympus Corporation, Shinjuku, Tokyo, Japan) to detect micro-cracks and surface defects. Only teeth without defects were selected for this study. In an attempt to standardize the substrate, each dental crown was submitted to a mineral density analysis using a Dual Energy X-ray Absorptiometry method (Lunar DPX-IQ, GE Medical Systems, Madison, Wisconsin, USA). Samples were then selected according to their mineral density, which should not overtake the limits of a pre-established interval of $3.0 \pm 0.2$ $\mathrm{g} / \mathrm{cm} 3$, as described in previous studies [18-19]. After selection, the teeth were stored in Milli-Q water (Millipore, Merck KGaA, Darmstadt, Germany) at $5^{\circ} \mathrm{C}$ until the beginning of the experimental phase (Figure 1A).

\section{Specimen Preparation}

The crowns were cut at the cementumenamel junction using a low-speed diamond saw under water-cooling (LABCUT 1010, Extec, Enfield, CT, USA) (Figure 1A). In an endeavor to standardize the dental enamel area that would receive the treatments, all the crowns were embedded in self-polymerizing acrylic resin. Each crown was placed with the middle third of buccal face supported on the plunger of an anesthetic cartridge that was fixed to the base of a Sample Cup mold (Buehler, Lake Buff, IL, USA) for embedding the samples. After the acrylic resin polymerization the plunger was removed, leaving only a $50.2 \mathrm{~mm}^{2}$ circular window of exposed enamel on the buccal surface (Figure 1B).

\section{Exposure of the specimens to treatment agents}

On the enamel surface was deposited with a micropipette (Labopette, Hirschmann Laborgeräte $\mathrm{GmbH}$ \& Co. KG, Eberstadt, Germany) (Figure 1C) $100 \mu \mathrm{l}$ of artificial saliva (calcium chloride $0.21 \mathrm{~g}$, potassium chloride $4.8 \mathrm{~g}$, sodium chloride $3.4 \mathrm{~g}$, magnesium chloride $0.27 \mathrm{~g}$, potassium phosphate $1.32 \mathrm{~g}$, sodium benzoate $1 \mathrm{~g}$, sodium carboxymethylcellulose $25 \mathrm{~g}$, sorbitol $120 \mathrm{~g}$, distilled water 4,850ml, $\mathrm{pH}=7.0$ ) $[9,16]$. A syringe was used to apply $1 \mathrm{ml}$ of bleaching agent on each specimen. The bleaching agent remained in contact with enamel for the time recommended by the manufacturer (Table I). In G7 (positive control) enamel surfaces were etched with $1 \mathrm{ml}$ of $37 \%$ phosphoric acid for 15 seconds. 
After each treatment time, the products were removed with $10 \mathrm{ml}$ of Milli-Q water using a syringe and the resultant liquid content was collected in polypropylene vials (Figure 1E). In G8 (negative control - no treatment) the specimens remained immersed in Milli-Q water. Collections for chemical analysis of the elements calcium and phosphorus were performed during the seven first days as well as on the 14th day of treatment. All collections and measurements were systematically made under the same experimental conditions.
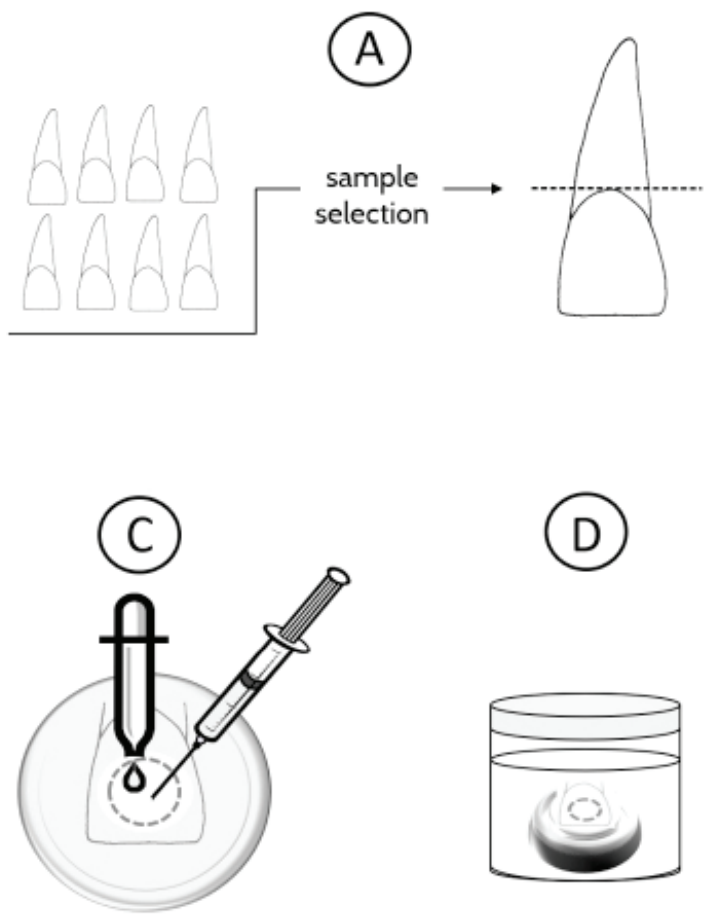

Figure I - Schematic representation of the methodology used in study.
After the application period, the specimens were cleaned with a toothbrush (Oral-B EndTufted Brush, Gillette do Brasil, Brasil) for 30 seconds [6]. During the remaining daily time, the specimens were individually stored in polypropylene vials with $10 \mathrm{ml}$ of artificial saliva at $37^{\circ} \mathrm{C}$ which was changed daily. The specimens were maintained in an environment with 100\% of relative humidity during all the experimental stages (Figure 1D).

\section{Atomic Emission Spectrometry Analysis}

The concentration (mg/l) of calcium and phosphorus in the collected samples was quantified by Inductively Coupled Plasma Atomic Emission Spectrometer (ICP-AES, SPECTRO Analytical Instruments $\mathrm{GmbH}$, Germany). Solutions collected from the negative control group (Milli-Q water) were used as blank solutions since they do not contain any detectable amount of the analyte of interest, is typically used for calibration purposes (Figure 1E).

The values obtained for each analyzed element were deducted from the initial concentration of these elements in the artificial saliva used and from the values of these elements 
found in the gels used (bleaching agents and phosphoric acid).

\section{Surface Morphology Analysis}

All the specimens were molded with vinyl polysiloxane impression material (Perfectim System, J. Morita USA, INC. California, USA) before the treatments began, and after the end of the experimental phase. The molds were cut at the limit of the crown, fixed on stubs and gold sputtered (SCD050, Bal-Tec, Tapematic, USA). All the electron micrographs were taken at the same working distance, at an original magnification of 1500X, using a JXA-6400 scanning electron microscope (JXA-6400, JEOL USA, INC) (Figure 1E).

\section{Statistical Analysis}

The software GraphPad Prism version 4.0 for Windows (GraphPad Software) was used. The data of the calcium and phosphorus ions were submitted to different statistical analyses utilizing a nonparametric repeatedmeasures Friedman's test followed by Dunn's multiple comparisons test to evaluate significant differences among the treatment agents and the treatment days at $1 \%$ level of significance.

\section{RESULTS}

\section{Spectrometry analysis of the chemical elements}

Table II shows the mean concentration values and standard deviations of the chemical elements calcium and phosphorus found in the gel removed from the specimens per group. None of the chemical elements analyzed were present in G8 (negative control).
Table II - Mean values in $\mathrm{mg} / \mathrm{l}$ and standard deviations ( \pm ) chemical elements analyzed

\begin{tabular}{|c|c|c|}
\hline GROUPS & Calcium & Phosphorus \\
\hline G1 & $0.36 \pm 0.05 a$ & $0.12 \pm 0.01 \mathrm{~A}$ \\
\hline G2 & $0.40 \pm 0.03 a$ & $0.13 \pm 0.02 \mathrm{~A}$ \\
\hline G3 & $0.36 \pm 0.04 a$ & $0.11 \pm 0.01 \mathrm{~A}$ \\
\hline G4 & $0.40 \pm 0.03 a$ & $0.13 \pm 0.02 \mathrm{~A}$ \\
\hline G5 & $0.73 \pm 0.05 b$ & $0.22 \pm 0.02 \mathrm{~B}$ \\
\hline G6 & $0.77 \pm 0.01 b$ & $0.28 \pm 0.04 \mathrm{~B}$ \\
\hline G7 (positive control) & $1.23 \pm 0.02 b$ & $0.38 \pm 0.02 B$ \\
\hline G8 (negative control) & no detection & no detection \\
\hline \multicolumn{3}{|c|}{$\begin{array}{l}\text { Different superscript letters in a row indicate significant statistica } \\
\text { differences among the groups }(p \leq 0.01)\end{array}$} \\
\hline
\end{tabular}

Theresultsweresimilarfor the two elements analyzed. No statistically significant difference was found among groups treated with hydrogen peroxide-based agents (G1, G2, G3, and G4) ( $p>0.01)$, irrespective of their concentration and acidity. Similarly, there were no significant differences between groups treated with either $10 \%$ or $16 \%$ carbamide peroxide-based agents (G5 and G6, respectively). Moreover, the results of mineral loss observed in groups G5 and G6 were comparable to the ones observed in the positive control group (G7), whose samples were treated with $37 \%$ phosphoric acid $(\mathrm{p}>0.01)$. On the other hand, significant differences were detected when agents based on hydrogen peroxide were compared with those based on carbamide peroxide or $37 \%$ phosphoric acid, with the last three ones presenting higher values of mineral loss $(\mathrm{p}<0.01)$.

When the factor under study was the treatment time, there were no statistical differences between the different periods evaluated ( $p>0.01)$. The regularity in the daily values of calcium and phosphorus found in gel collected during 14 days can be observed in Figure 2. 

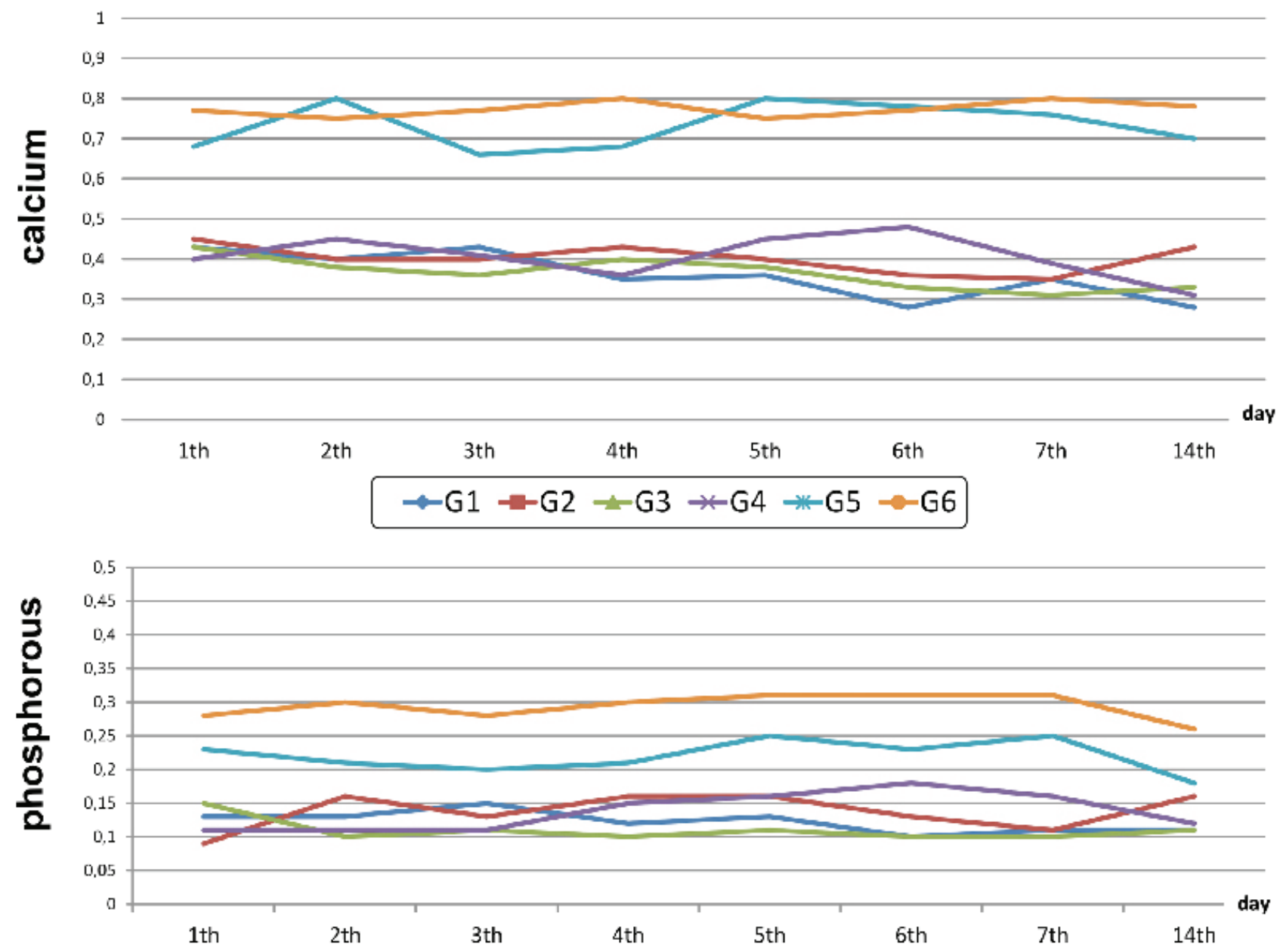

Figure 2 - Daily mean values (mg/l) of calcium and phosphorous during period of bleaching treatment.

\section{Scanning Electron Microscopy}

The photomicrographs of G8 (negative control), concerning the specimens that only remained immersed in Milli-Q water, did not show any alterations on enamel surfaces. The surface morphology of enamel submitted to different treatments showed distinct changes in the levels of its original topography. Figures 3 and 4 present electron micrographs that represent images of each of the experimental and control groups.

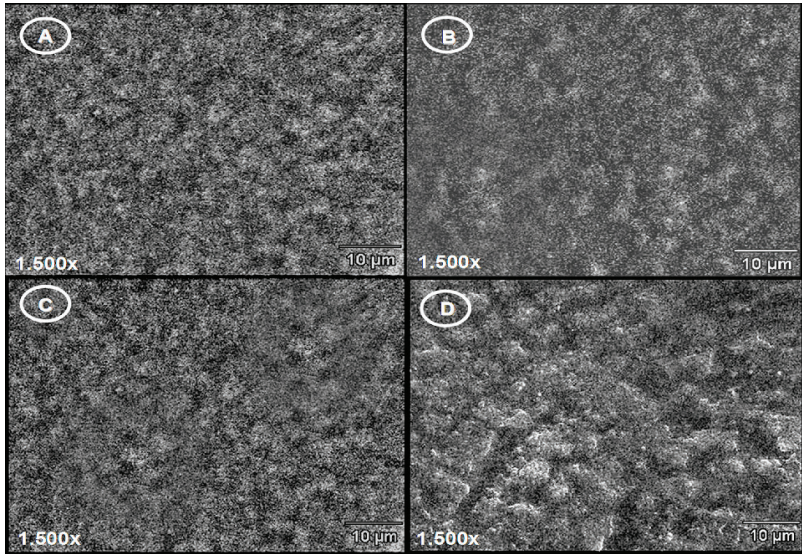

Figure 3 - Enamel surface morphology. (A) G1- 7.5\% hydrogen peroxide, $\mathrm{pH}=9.0$; (B) $\mathrm{G} 2-9.5 \%$ hydrogen peroxide, $\mathrm{pH}=9.0$; (C) G3 - 7.5\% hydrogen peroxide, pH=7.0; (D) G4 - 9.5\% hydrogen peroxide, $\mathrm{pH}=7.0$. Scanning Electron Microscopy (x1500). 


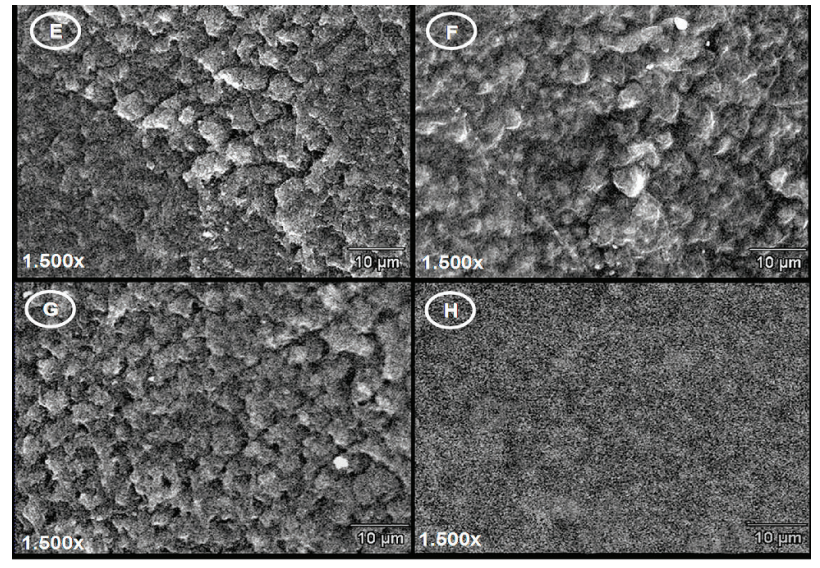

Figure 4 - Enamel surface morphology. (E) G5 - 10\% carbamide peroxide, $\mathrm{pH}=5$; (F) $\mathrm{G} 6$ - 16\% carbamide peroxide, $\mathrm{pH}=5$; (G) G7- 37\% phosphoric acid for 15 seconds; $(H)$ aspect of the initial electron micrograph of all the groups and G8 - Milli-Q water. Scanning Electron Microscopy (x1500).

\section{DISCUSSION}

The effectiveness and safe use of dental bleaching have been widely spread, and it is nowadays an important option for treatment in the field of aesthetic dentistry. However, many concerns have been raised about its adverse effects. Among these side-effects, one of the most discordant points seems to be related to alterations in the structure of dental enamel and its mineral content. These controversies may be related to differences in $\mathrm{pH}$, concentration, and composition of commercial bleaching agents, as well as treatment duration, dosage, and intrinsic properties of tooth substrate. In particular, natural variations in enamel morphology and mineral content have been reported to play a significant role [9]. In this sense, it has been stated that well-established criterion is necessary to enable comparative analysis of the effect of bleaching agents on enamel [20]. This requirement may be fulfilled by creating baseline data of untreated enamel surfaces before they are submitted to the bleaching protocol. This measure would facilitate not only the comparison of studies conducted by different research groups but also assure a more comprehensive analysis of the obtained results [21]. In an endeavor to eliminate this possible variable, all the central incisors used in this study were submitted to a densitometry analysis, so that the obtained results reflect the different effects caused by the agents employed (bleaching gels and phosphoric acid) with minimal influence of differences usually derived from the substrate used.

Means of an ICP-AES performed the analysis of the mineral content of enamel presented in this study. The use of this piece of equipment is justified by its high sensitivity and specificity [22]. Moreover, ICP-AES can function as a non-destructive method in the analysis of mineralized tissues and reveal alterations in enamel during and after dental bleaching treatments.

As in other studies that have evaluated mineral changes $[1,4,12,13,15]$ in bleached enamel, the results of this study have shown that the bleaching procedure resulted in a loss of calcium and phosphorus from enamel, which suggests a process of demineralization of the dental substrate. As previously reported, continued bleaching causes progressive enamel demineralization with concomitant enamel matrix degradation of a layer probably only a few microns deep. This phenomenon has been related to the presence of hydrogen peroxide and urea produced by the decomposition of carbamide peroxide during the bleaching treatment [9]. However, the rationale behind it seems to be more complicated as far as the results of the present study are taken into account. In this study, different concentrations of bleaching agents with the same $\mathrm{pH}$ had no influenced on the amounts of calcium and phosphorus obtained. However, when assuming the bleaching agent acidity as a variable, it was evidenced that the lower the $\mathrm{pH}$ of the gel, the larger the amounts of calcium and phosphorus detected in the samples collected, by which the first null hypothesis must be rejected.

The acidity of the bleaching gel can be credited to different factors such as the presence 
of citric acid, acetic acid or phosphoric acid in the composition of home bleaching agents [23]. Another factor that seems to contribute to this acidity is the chemical characteristic of the thickening agent present in home bleaching agent. Carbopol, for instance, is a polyacrylic acid polymer used as a thickening agent. In aqueous medium, unneutralized dispersions of carbopol dissociate achieving a $\mathrm{pH}$ range of 2.53.5 depending on the polymer concentration [24]. In addition to acting as a demineralizing agent6, this acidic medium created by Carbopol propitiates a slower release of oxygen, once the degradation of peroxides is delayed in mediums with low $\mathrm{pH}$ [25]. That said, it is possible that the effects of carbopol on dental hard tissues act synergistically with free radicals, merely potentiating an increased mineral loss owing to the use of other agents [23].

Amongst the evaluated agents, the 10\% and $16 \%$ carbamide peroxide resulted in higher daily losses of the quantified elements, even when compared with the hydrogen peroxide agents. The higher demineralization with carbamide peroxides can be credited to the fact that the bleaching agent used presents a $\mathrm{pH}$ below the critical point to start the demineralization process in human dental enamel [26]. Furthermore, it should be considered that these products remained in close contact with the enamel surface for a longer time, resulting in a prolonged action of Carbopol when compared with the other bleaching gels used. This direct contact with enamel for prolonged times has increased concerns about the potential adverse effects of these agents on enamel [5,7]. As previously described, it is important to consider the exposure time and how often the product is used, especially when making judgments on the effects of highly acidic or highly basic solutions [17]. Therefore the use of hydrogen peroxide bleaching agents that require shorter periods of direct contact with dental enamel could be an option in an endeavor to reduce the hazardous effects of these products on dental mineral content. Still, regarding the use of carbamide bleaching agents with carbopol, it is important to mention that other studies observed a significant decrease in enamel microhardness when compared with bleaching agents without Carbopol $[6,27]$.

The present study also evaluated the mineral content alterations as a function of time. No oscillations in the measurements of calcium and phosphorus were noted with the subsequent daily applications of the bleaching gels, by which the second null hypothesis is accepted. When dissolution of the superficial enamel prism layer occurs during application of the bleaching gel, a subsurface layer is exposed, presenting the same mineral composition as that of the previous one [26]. This fact may justify the results presented in this study as far as the time of treatment is concerned.

The electron micrographs obtained in this study show similar images as compared to the ones presented in other studies [10]. The superficial topographical alterations most perceived were caused by bleaching agents with lower $\mathrm{pH}$, which remained in close contact with the dental enamel for a more extended period. Although these morphological changes appeared in enamel surfaces treated with the most acidic gels, all the groups submitted to bleaching treatments demonstrated some level of surface modification in the original topography. Similar alterations have also been found by other authors $[11,28,29]$. Thus, it has been suggested that lower peroxide concentration and shorter treatment times should be applied during the bleaching treatment to reduce the possibility of alterations on enamel surface, as the ones presented in this study [15]

Taking into account the results obtained in this in vitro study it was concluded that concentration of bleaching agents might not influence alterations in mineral enamel content. The most evident alterations in mineral content and surface morphology of enamel may be 
related to using more acidic products. It was also concluded that repeated applications of bleaching agents might not influence the mineral content of enamel surface. It must be considered, however, that the results presented in this study just predict a clinical situation and that further research is necessary as far as the oral environment is taken into account. An important factor to be considered, for example, is the possible reversibility of the internal or superficial alterations of enamel during and after the bleaching treatment. Therefore, further in situ and in vivo research would be of great assistance to validate the results of this study and determine the clinical implications of the mentioned enamel alterations. Additional research should focus on the effects of carbopol in the mineral loss during the bleaching treatment. In this sense, the development of innovative harmless thickeners could be of great interest.

Finally, dental bleaching process involves the direct contact of the whiteness product on surface teeth. This direct contact with enamel for prolonged times can potentially increase undesired effects of these agents on enamel. Also, the use of faster action products is recommended.

\section{ACKNOWLEDGEMENT}

The first author was supported by CAPES/ MEC (Agency for the institutional stimulus of the post-graduate programs in Brazil).

\section{REFERENCES}

1. Lee KH, Kim HI, Kim KH, Kwon YH. Mineral loss from bovine enamel by a $30 \%$ hydrogen peroxide solution. J Oral Rehabil. 2006 Mar;33(3):229-33.

2. Haywood VB, Heymann HO. Nightguard vital bleaching. Quintessence Int. 1989 Mar;20(3):173-6.

3. Haywood VB, Leech T, Heymann HO, Crumpler D, Bruggers K. Nightguard vital bleaching: effects on enamel surface texture and diffusion. Quintessence Int. 1990 0ct;21(10):801-4.

4. Llena C, Esteve I, Forner L. Effect of Hydrogen and Carbamide Peroxide in Bleaching, Enamel Morphology, and Mineral Composition: In vitro Study.J Contemp Dent Pract. 2017 Jul 1;18(7):576-582.
5. Efeoglu N, Wood D, Efeoglu C. Microcomputerised tomography evaluation of 10\% carbamide peroxide applied to enamel. J Dent. 2005 Aug;33(7):561-7.

6. Basting RT, Rodrigues AL Jr, Serra MC. The effect of $10 \%$ carbamide peroxide, carbopol and/or glycerin on enamel and dentin microhardness. Oper Dent 2005 Sep-0ct;30(5):608-16.

7. Cvikl B, Lussi A, Moritz A, Flury S. Enamel Surface Changes After Exposure to Bleaching Gels Containing Carbamide Peroxide or Hydrogen Peroxide. Oper Dent. 2016 Jan-Feb;41(1):E39-47.

8. Tezel H, Ertaş OS, Ozata F, Dalgar H, Korkut ZO. Effect of bleaching agents on calcium loss from the enamel surface. Quintessence Int. 2007 Apr;38(4):339-47.

9. Yeh ST, Su Y, Lu YC, Lee SY. Surface changes and acid dissolution of enamel after carbamide peroxide bleach treatment. Oper Dent. 2005 JulAug;30(4):507-15.

10. Soares DG, Ribeiro AP, Sacono NT, Loguércio AD, Hebling J, Costa CA. Mineral loss and morphological changes in dental enamel induced by a $16 \%$ carbamide peroxide bleaching gel. Braz Dent J. 2013 Sep-0ct;24(5):517-21

11. Türkun M, Sevgican F, Pehlivan Y, Aktener BO. Effects of $10 \%$ carbamide peroxide on the enamel surface morphology: a scanning electron microscopy study. J Esthet Restor Dent. 2002;14(4):238-44.

12. Severcan F, Gokduman K, Dogan A, Bolay S, Gokalp S. Effects of in-office and at-home bleaching on human enamel and dentin: an in vitro application of Fourier transform infrared study. Appl Spectrosc. 2008 Nov;62(11):1274-9.

13. Justino LM, Tames DR, Demarco FF. In situ and in vitro effects of bleaching with carbamide peroxide on human enamel. Oper Dent. 2004 MarApr;29(2):219-25.

14. Rajesh A, Ranganath L, Kumar KP, Rao BS. Surface Morphological Changes in Human Enamel Following Bleaching: An in vitro Scanning Electron Microscopic Study. J Contemp Dent Pract. 2012 May 1;13(3):405-15.

15. Bistey T, Nagy IP, Simó A, Hegedus C. In vitro FT-IR study of the effects of hydrogen peroxide on superficial tooth enamel. J Dent. 2007 Apr;35(4):32530.

16. de Medeiros CL, González-López S, Bolaños-Carmona MV, SanchezSanchez P,Bolaños-Carmona J. Effects of phosphoric acid on bovine enamel bleached with carbamide peroxide. Eur J Oral Sci. 2008 Feb;116(1):66-71.

17. Price RB, Sedarous M, Hiltz GS. The pH of tooth-whitening products. JCan Dent Assoc. 2000 Sep:66(8):421-6.

18. Elliott JC, Wong FS, Anderson P, Davis GR, Dowker SE. Determination of mineral concentration in dental enamel from $X$-ray attenuation measurements. Connect Tissue Res. 1998;38(1-4):61-72

19. Huang $T T$, Jones AS, He LH, Darendeliler MA, Swain MV. Characterisation of enamel white spot lesions using X-ray micro-tomography.J Dent. 2007 Sep;35(9):737-43

20. Spalding M, Taveira LA, de Assis GF. Scanning electron microscopy study of dental enamel surface exposed to $35 \%$ hydrogen peroxide: alone, with saliva, and with $10 \%$ carbamide peroxide. J Esthet Restor Dent. 2003;15(3):154-64.

21. Wong FS, Anderson P,Fan H, Davis GR. X-ray microtomographic study of mineral concentration distribution in deciduous enamel. Arch Oral Biol. 2004 Nov;49(11):937-44.

22. Skoog DA, Holler FJ, Nieman TA. Principles of instrumental analysis. 5 ed. Philadelphia: Saunders College Publication; 1998.

23. Bitter NC. A scanning electron microscopy study of the effect of bleaching agents on enamel: a preliminary report. J Prosthet Dent. 1992 Jun;67(6):852-5. 
24. Schwarz TW, Levy G. A report on the oxidative degradation of neutralized carbopol. J Am Pharm Assoc Am Pharm Assoc 1958 Jun;47(6):442-3.

25. Chen JH, Xu JW, Shing CX. Decomposition rate of hydrogen peroxide bleaching agents under various chemical and physical conditions. J Prosthet Dent. 1993 Jan;69(1):46-8.

26. Ten Cate AR. Oral Histology: Development, Structure and Function. 5 ed. St Louis: Mosby; 1998.
27. Toteda M, Philpotts CJ, Cox TF, Joiner A. Evaluation of a 6\% hydrogen peroxide tooth-whitening gel on enamel microhardness after extended use. Quintessence Int. 2008 Nov;39(10):853-8.

28. Fu B, Hoth-Hannig W, Hannig M. Effects of dental bleaching on micro- and nano-morphological alterations of the enamel surface. Am J Dent. 2007 Feb;20(1):35-40.

29. Sa Y,Wang Z, Ma X, Lei C, Liang S, Sun L, et al. Investigation of three homeapplied bleaching agents on enamel structure and mechanical properties: an in situ study. J Biomed Opt. 2012 Mar;17(3):035002. doi: 10.1117/1. JB0.17.3.035002.

\section{Alessandra Pereira de Andrade \\ (Corresponding address)}

Restorative Dentistry, School of Dentistry - University São

Francisco - Bragança Paulista - SP - Brazil.

Avenida São Francisco de Assis, 218 - Jardim São José,

Bragança Paulista - SP, CEP: 12916-900

Phone: +55 11 2454-8000

Date submitted: 2017 0ct 20

email: alessandra.andrade@usf.edu.br

Accept submission: 2018 Feb 26 